\title{
Physicochemical properties and microbial control of chestnuts (Castanea sativa) coated with whey protein isolate, chitosan and alginate during storage
}

\author{
Luana Fernandes $^{\mathrm{a}}$, Ermelinda L. Pereira ${ }^{\mathrm{a}}$, Maria do Céu Fidalgo ${ }^{\mathrm{b}}$, Auryo Gomes ${ }^{\mathrm{b}}$, \\ Elsa Ramalhosa ${ }^{\mathrm{a}, *}$
}

${ }^{\text {a }}$ Centro de Investigação de Montanha (CIMO), Polytechnic Institute of Bragança, Portugal

${ }^{\mathrm{b}}$ School of Agriculture, Polytechnic Institute of Bragança, Portugal

\section{A R T I C L E I N F O}

\section{Keywords:}

Chestnut

Edible coatings

Postharvest quality

Microbial counts

Storage life

\begin{abstract}
A B S T R A C T
Chestnuts (Castanea sativa Mill.) were subjected to three different coatings - chitosan, alginate and whey protein and stored under refrigeration $\left(0{ }^{\circ} \mathrm{C}, 90 \% \mathrm{HR}\right)$ during 6 months. The shell color parameters $\mathrm{a}^{*}, \mathrm{~b}^{*}$ and $\mathrm{C}$ showed a tendency to decrease in all samples, while $\mathrm{L}^{*}$ increased in alginate coated chestnuts. Application of coatings had no effect on moisture, water activity $\left(\mathrm{a}_{\mathrm{w}}\right)$, as well as in the color inside the fruit and texture parameters (maximum penetration force and hardness). On the contrary, acidity and total soluble solids increased during storage in coated samples. The chitosan coating reduced chestnuts microorganisms' counts after 6 months of storage, compared to the control. In conclusion, chitosan coating improved the microbial quality of chestnuts, so it is a possible preservation alternative and an effective method to solve the problem of microbial growth in chestnuts throughout storage.
\end{abstract}

\section{Introduction}

Chestnut (Castanea sativa Mill.) is an important tree species, economically explored for fruit and wood, having great connection with the Portuguese territory, especially the North of Portugal. In Trás-osMontes region (NE Portugal), this crop is one of the main source of income in some rural areas. In 2017, the North of Portugal produced 25,652 ton of chestnut (INE, 2017), and the production of chestnuts has increased from year to year. In the last years, the consumers have been showing an increased interest in chestnut because of their nutritional qualities and potential beneficial health effects (Blomhoff et al., 2006). However, the chestnuts industry and local producers face several problems during their storage. Particularly, chestnuts are very sensitive to mold growth. Furthermore, during storage, the chestnuts dry easily, resulting in flavor decrease and weight loss, contributing to significant economic losses. So, chestnuts producers are very interested in improving the marketability, not only by increasing chestnuts' shelf-life but also by developing new products. In this way, the application of new food technologies will bring important economic benefits to producers, beyond allowing the preservation of product quality for longer periods of time. Edible coatings can be a new treatment to maintain chestnuts quality during storage, since edible coatings are mentioned to protect the food products from mechanical, physical, chemical and microbial damages (Campos et al., 2011; Lin and Zhao, 2007). However, choosing the suitable coating definitely affects the effectiveness of the treatment. A range of polymers (proteins, polysaccharides, lipids) can be used in edible coating formulation. Chitosan and alginate are polysaccharides successfully used in fruits (Varasteh et al., 2017; Chiabrando and Giacalone, 2016), as well as whey isolate protein (Cisneros-Zevallos and Krochta, 2003; Alleoni et al., 2006). Particularly, chitosan coatings showed to have antifungal activity and antimicrobial properties during storage (Chien et al., 2007; Zhang and Quantick, 1998). On the other hand, whey protein coatings have increasing their interest because they can be obtained from dairy industry by-products and act as oxygen barrier (Regalado et al., 2006). Alginate coatings also have been reported to be good oxygen barriers (Conca and Yang, 1993) and to reduce the natural microflora counts (Amanatidou et al., 2000). Thus, each polymer used in the formulation of edible coatings has specific properties, being necessary to investigate their effect on each food, in order to enhance their properties.

Of our knowledge, until now there is no available scientific literature about the use of edible coatings for maintaining the quality and extending the shelf life of the European chestnut (Castanea sativa). However, few studies on the effect of edible coatings have been

\footnotetext{
* Corresponding author.

E-mail address: elsa@ipb.pt (E. Ramalhosa).
} 
conducted on other different species of chestnuts, in particularly on Chinese chestnut (Castanea molissima) (Gounga et al., 2007, 2017), using whey protein isolate. Thus, the objective of this study was to evaluate, for the first time, the effect of three edible coatings (whey protein isolate, chitosan and alginate) on the quality of the European chestnut (Castanea sativa), during cold storage at $0{ }^{\circ} \mathrm{C}$ and over $1,2,3$ and 6 months of storage. The following physicochemical characteristics were evaluated: visual appearance, $\mathrm{a}_{\mathrm{w}}$, color, texture, $\mathrm{pH}$ and titratable acidity, as well as, microbial quality. Furthermore, by solving the problem of microbial growth and weight loss during storage, this research can contribute to reduce chestnuts losses, and to increase the economic return of local producers and chestnuts sector.

\section{Material and methods}

\subsection{Samples}

Fresh chestnuts (Castanea sativa) were acquired directly to a chestnut enterprise of Bragança (Bragança, NE Portugal) in January 2019. After transportation to the laboratory, the chestnuts were hotwater treated. This process consisted of placing the chestnuts in a bath containing hot water at a temperature of $47-50^{\circ} \mathrm{C}$ for $30 \mathrm{~min}$ and then pouring them in cold water to lower the temperature. This process is recommended by the Portuguese government (DAGV, 2018) to be applied to chestnuts that will be exported to other countries. However, some chestnuts companies apply this process to chestnuts that will be sold fresh. To dry the exterior water, the samples were rested in trays with absorbent paper for $36 \mathrm{~h}$.

\subsection{Edible coatings}

Three edible coatings - whey protein isolate, chitosan and alginate were applied according to the method used by Nair et al. (2018), with slight modifications. A total of 36 portions of $300 \mathrm{~g}$ of chestnuts each were divided into 3 groups and were immersed in the following solutions:

(1) An alginate solution was prepared by dissolving sodium alginate powder in distilled water for $1 \mathrm{~h}$, at $70{ }^{\circ} \mathrm{C}$. After cooling, glycerol was added to a final concentration of $10 \%(\mathrm{v} / \mathrm{v})$. The chestnuts were immersed in the alginate solution $(2 \%, \mathrm{w} / \mathrm{v})$ for $1 \mathrm{~min}$. Then the residual alginate solution was allowed to drain for $5 \mathrm{~min}$ before immersing the samples in $\mathrm{CaCl}_{2}(2 \%, \mathrm{w} / \mathrm{v})$ for $1 \mathrm{~min}$, to induce spontaneous cross-linking reactions;

(2) A chitosan solution $(2 \%, \mathrm{w} / \mathrm{v})$ was prepared by dissolving it in glacial acetic acid $(1 \%, \mathrm{v} / \mathrm{v})$ in a homogenizer (IKA T25 ULTRATURRAX, Germany) at a speed of $800 \mathrm{rpm}$ for $2 \mathrm{~min}$ at room temperature with a final $\mathrm{pH}$ of 5.2 . Glycerol $(0.75 \%, \mathrm{v} / \mathrm{v})$ was added as plasticizer. The chestnuts were immersed in the chitosan solution for $1 \mathrm{~min}$. The residual chitosan solution was allowed to drain for $3 \mathrm{~min}$;

(3) Commercial whey protein isolate was obtained by Prozis (Braga, Portugal). Whey protein isolate $(2 \%, \mathrm{w} / \mathrm{v})$ were dissolved in distilled water and glycerol to a final concentration of $2.5 \%(\mathrm{v} / \mathrm{v})$. After that, the solution was heated under stirring at $80{ }^{\circ} \mathrm{C}$ for $30 \mathrm{~min}$. The chestnuts were immersed in whey protein isolate for $1 \mathrm{~min}$ and leave to air for $3 \mathrm{~min}$.

Then, all treated samples were put in plastic trays.

\subsection{Storage}

The coated samples prepared in Section 2.2, as well as fresh uncoated chestnuts (control), were stored under refrigeration $\left(\mathrm{T}=0.03 \pm 0.57{ }^{\circ} \mathrm{C}, \mathrm{RH}=90.7 \pm 3.1 \%\right)$ during 6 months, in the company where chestnuts were acquired. The temperature and relative humidity (RH) of the cold room of the chestnut company were monitored during storage, with a data logger (blulog, HTLDL-112). After 1, 2,3 and 6 months of storage, three portions $(300 \mathrm{~g})$ of each treatment (coated and uncoated) were collected and immediately transported to the laboratory to be analysed.

\subsection{Color}

Chestnuts' color was evaluated both outside (shell) and inside the fruit, with a colorimeter Minolta CR-400 (Osaka, Japan), using the CIELAB scale, namely: $L^{*}, a^{*}$ and $b^{*}$ coordinates, where $L^{*}$ varies between 0 (black) and 100 (white), the chromatic $a^{*}$ axis extends from green $\left(-a^{*}\right)$ to red $\left(+a^{*}\right)$, and the chromatic $b^{*}$ axis extends from blue $\left(-b^{*}\right)$ to yellow $\left(+b^{*}\right)$. Furthermore, the Chroma $\left(C^{*}\right)$ was also determined. In order to analyse color changes due to the application of edible coatings, the total color difference $\left(\Delta \mathrm{E}^{*}\right)$ was also calculated according to the following equation:

$\Delta \mathrm{E}^{*}=\sqrt{\left(\Delta \mathrm{L}^{*}\right)^{2}+\left(\Delta \mathrm{b}^{*}\right)^{2}+\left(\Delta \mathrm{a}^{*}\right)^{2}}$

where $\Delta$ was the difference of the parameters' values after the treatments along storage and the beginning (fresh sample, day 0 ).

\subsection{Weight loss, water activity $\left(a_{w}\right)$ and moisture}

Weight loss (WL) was determined according to Eq. 2:

$W L=\frac{M_{0}-M}{M_{0}} \times 100$

where $M_{0}$ is the initial mass of chestnuts at day 0 (in coated samples, $M_{0}$ was determined after edible coating application) and $\mathrm{M}$ is the mass of chestnuts after storage time.

Water activity $\left(\mathrm{a}_{\mathrm{w}}\right)$ was determined with a portable water activity meter (Novasina, LabSwift-aw, Lachen, Switzerland). This parameter was evaluated on three samples before applying any treatment (control) and on all samples during storage. Moisture content was determined by drying the samples to a constant weight at $105^{\circ} \mathrm{C}$.

\subsection{Texture}

Texture profile analysis was performed on a TA.XT. Plus texture analyser (Stable Microsystems, Godalming, UK). The maximum penetration force $(\mathrm{N})$, the distance at which it occurs (elasticity) $(\mathrm{mm})$ and the area below the curve between force and time (indicative of hardness) were determined by penetration with a $2 \mathrm{~mm}$ cylinder probe and a test speed of $1.0 \mathrm{~mm} / \mathrm{s}$. These parameters were determined on fruit without dark brown outer shell.

\subsection{Titratable acidity and total soluble solids}

Titratable acidity (TA) was determined by titrimetric analysis, consisting of a titration with $0.10 \mathrm{~mol} / \mathrm{L} \mathrm{NaOH}$. Approximately, $10 \mathrm{~g}$ of each sample (previously ground) was mixed with $50 \mathrm{ml}$ of water and put on heating under reflux for $30 \mathrm{~min}$. Then, the resultant solution was transferred to a glass balloon of $100 \mathrm{ml}$ and after filtration a precise volume $(20 \mathrm{ml})$ was transferred to a beaker with a stirrer. Then, the $\mathrm{pH}$ of the solution was monitored continuously in order to obtain the titration curve. The $\mathrm{pH}$ at the equivalence point was established as 8.1, as indicated in the Portuguese standard (NP-1421, 1977). The values were expressed on mg citric acid /100 g dry weight (dw). The solution obtained for the acidity determination (after filtration) was also used to measure the total soluble solids (TSS) contents ( $\left.{ }^{\circ} \mathrm{Brix}\right)$ in an Abbe refractometer (Optic Ivymen System, Madrid, Spain). 


\subsection{Reducing sugars}

The extraction procedure used to determine the reducing sugars was described by Barreira et al. (2010), with slight modifications. Dried and defatted powder $(1.0 \mathrm{~g})$ was extracted with $5 \mathrm{ml}$ of $80 \%(\mathrm{v} / \mathrm{v})$ aqueous ethanol at $70{ }^{\circ} \mathrm{C}$ for $30 \mathrm{~min}$. The resulting suspension was centrifuged at $4,000 \mathrm{rpm}$ for $15 \mathrm{~min}$. The supernatant was used to determine the reducing sugars by the dinitrosalicylic acid (DNS) method. A calibration curve was obtained with glucose $(0.05$ to $0.65 \mathrm{~g} / \mathrm{L})$ and the results expressed on $\mathrm{mg}$ glucose $/ 100 \mathrm{~g}$ dry weight.

\subsection{Microbial quality}

Control (0 days) and coated samples during storage (1, 2, 3 and 6 months) were collected to determine the microbial quality of chestnuts. Three chestnuts of each sample was mixed with sterile peptone water solution and homogenized. Decimal dilutions were prepared in the same diluent and plated on appropriate media in duplicate. The growth media and incubation conditions were the following for the studied microorganisms: (I) Aerobic mesophilic at $30^{\circ} \mathrm{C}$ : Plate Count agar (PCA, Liofilchem, Italy) for 2 days at $30^{\circ} \mathrm{C}$; (II) Yeasts and molds: Dichloran Rose Bengal Chloramphenicol Agar (DRBC agar, Liofilchem, Italy) incubated at $25^{\circ} \mathrm{C}$ for 5 days. All counts were expressed as $\log _{10} \mathrm{cfu} / \mathrm{g}$ fresh sample.

\subsection{Statistical analysis}

The physicochemical and microbial results were statistically evaluated in order to check which ones were significantly different. The statistical analysis was performed using the MINITAB software (Minitab ${ }^{\circledR}$ 16, Pennsylvania State University, USA). The homogeneity of the variances was tested by Levene's test and the normality of the data was verified by Shapiro-Wilk test. The existence of significant differences among the different conditions was assessed by one-way analysis of variance (ANOVA) followed by Tukey's HSD (variances in the different groups were identical) or ANOVA Welch followed by GamesHowell test (variances in the different groups were no identical). A value of $p<0.05$ was considered to be statistically significant.

\section{Results and Discussion}

\subsection{Visual appearance}

The temperature and $\mathrm{RH}$ of during storage are described in Fig. 1. The temperature varied between -1 and $1{ }^{\circ} \mathrm{C}$, and the relative humidity between 86 and 96\%, remaining quite constant along the storage period. Fig. 2 shows the appearance of the uncoated (control) and coated chestnuts throughout storage. At the beginning ( 0 months), the coated samples were brighter than the control, after coating application, as expected. After 3 months of storage, the chitosan and alginate coated chestnuts maintained similar appearance to those of day 0 . On the contrary, whey protein coated chestnuts, as well as the uncoated chestnuts (control), showed some molds growth. At the end of storage (6 months), chitosan coated chestnuts showed the lowest molds growth. So, chitosan coating may retard microbial growth for 6 months of storage, while alginate coating only for 3 months of storage. On the other hand, whey protein does not seem to be a good alternative. Different results for whey protein were reported by Gounga et al. (2017), who mentioned that after 3 months (150 days), the sample stored at 7 and $25^{\circ} \mathrm{C}$ still had a glossy appearance; however, these authors used Chinese chestnuts (Castanea molissima) that were previously freeze-dried, which are different to the European ones.

\subsection{Color}

The changes in color parameters $\left(\mathrm{L}^{*}, \mathrm{a}^{*}, \mathrm{~b}^{*}, \mathrm{C}\right.$ and $\left.\Delta \mathrm{E}^{*}\right)$ of uncoated
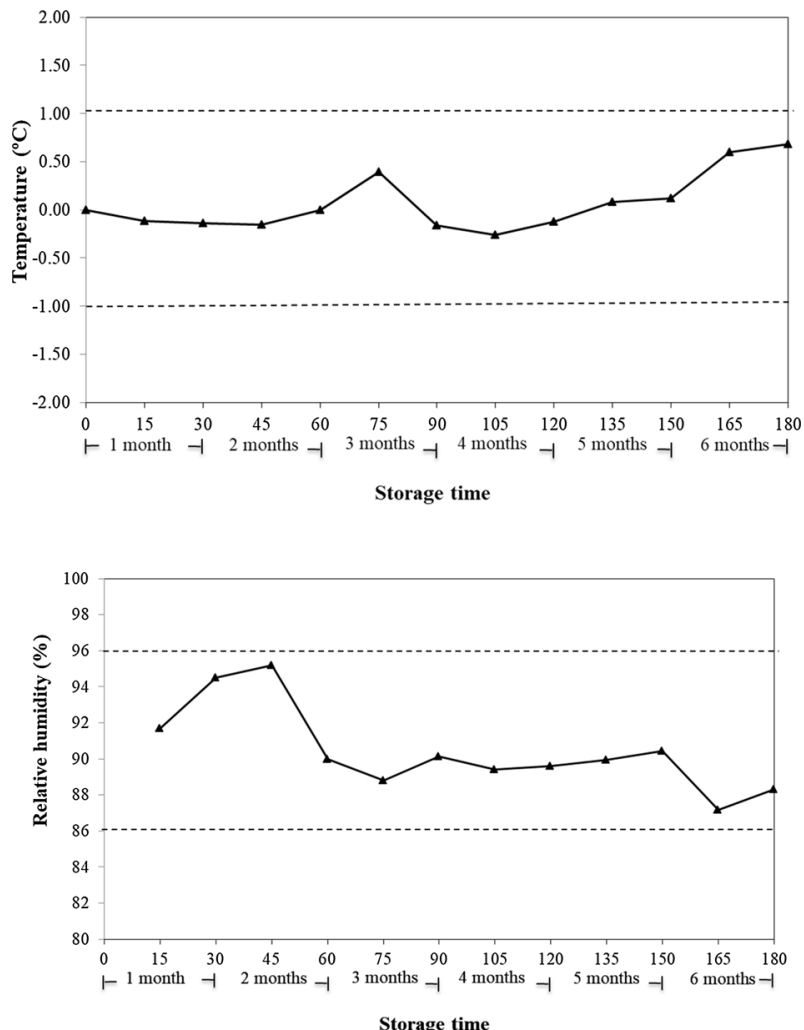

Fig. 1. Average values of temperature $\left({ }^{\circ} \mathrm{C}\right)$ and relative humidity (\%) measured by the data loggers during all storage.

(control) and coated chestnuts (shell and inside the fruit) throughout storage are shown in Table 1 . After 6 months of storage, it was impossible to measure the color parameters in chestnuts coated with alginate and whey protein, because many fruits showed molds growth. The shell color of chestnuts is a very important aspect because it greatly influences the moment of purchase by consumers. Regarding the $L^{*}$ values of shell, when comparing start to the end of storage ( 0 and 3 (whey protein) or 6 (chitosan and control) months, respectively), there were non-significant differences for chestnuts coated with chitosan and whey protein, as well as, in the control. On the contrary, for alginate coating an increase in the $L^{*}$ values was observed, when comparing 0 days (32.46) to 3 months (37.38), resulting in lighter samples. In more detail, after one month, all coated samples increased the $L^{*}$ values, probably because after the application of the edible coatings the chestnuts became brighter and lighter, as a result of the formation of the film around the fruit. A decline in $\mathrm{a}^{*}, \mathrm{~b}^{*}$ and $\mathrm{C}$ values were observed in all samples throughout storage. Between coated samples, after 3 months, non-significant differences in these parameters were found. Concerning total color variation $\left(\Delta \mathrm{E}^{*}\right)$ of the shell, all coated and control samples showed color modifications throughout storage. However, no significant color differences were found between treatments after 3 months of storage and between the control and the chitosan coated chestnuts after 6 months of storage.

Regarding the color inside the fruit, significant differences between the control and coated samples after 6 months of storage were observed in $L^{*}, b^{*}$ and $C$ parameters. The control samples showed the lowest values of $L^{*}$ (81.85), $b^{*}$ (21.21) and C (21.31) after 6 months of storage, which indicated a reduction in lightness, yellowness and chroma, respectively. Concerning storage time, the $L^{*}$ values decreased in almost every situation, while $\mathrm{a}^{*}$ increased in all samples indicative of redness. Concerning the total color variation, low values $(<8)$ were obtained for all treatments after 6 months of storage, being the results quite similar and suggesting that the application of coatings did not adversely influence the color inside the fruit. Furthermore it was interesting to 


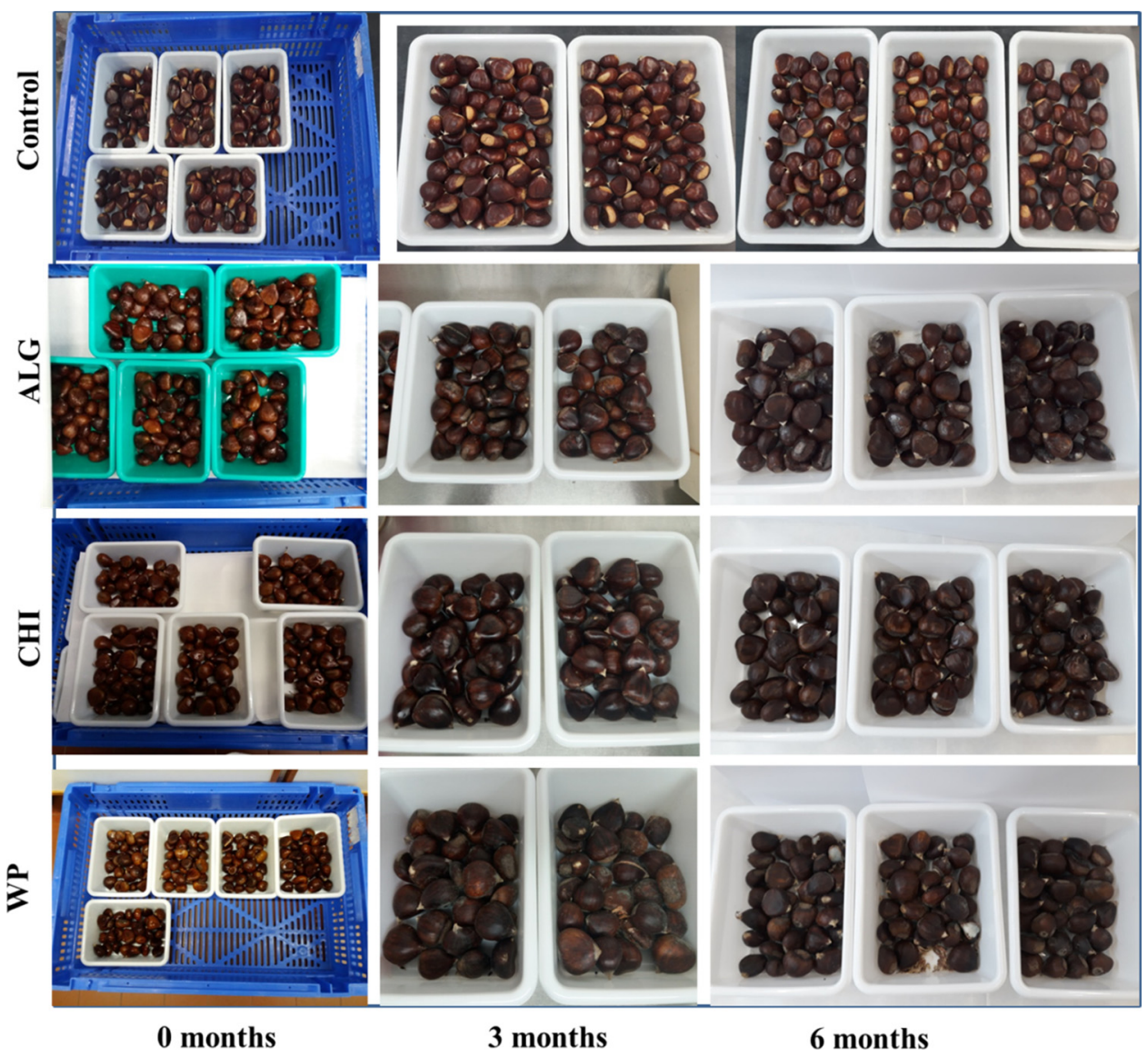

Fig. 2. Visual appearance of coated and control chestnuts during storage (0, 3 and 6 months). ALG - alginate, CHI - chitosan; WP - whey protein.

note that the total color variation values were higher in the shell than in the interior because the application of the coatings is external.

\subsection{Weight loss, moisture content and water activity $\left(a_{w}\right)$}

The weight loss is a crucial parameter, since every loss in weight can be translated into an economic loss. In the present work, the weight loss increased in all samples (coated and control) during storage. However, the weight loss was more pronounced in chestnuts coated with whey protein (between 1.63-14.60\%). The chitosan coating showed the lowest values of weight loss during storage, ranging between 0.93-2.63 $\%$. Differences in the ability of each coating to reduce weight loss may be attributed to the different thickness of each coating and moisture permeability, important factors from the view point of mass transfer rate (Yaman and Bayoindirli, 2002).The moisture content of chestnuts before coating treatments (day 0) was $46.7 \%$, similar to the values (5354\%) reported by Barreira et al. (2012). During all storage period, the values of moisture remained practically constant, between 42 and $56 \%$. In almost every situation, no significant differences $(\mathrm{p}>0.05)$ were found between treatments and time (Table 2). So, the coatings did not affect the moisture content during storage. Regarding water activity, the values maintained high during all storage, ranging from 0.954 (alginate coating at 6 months) to 0.978 (whey protein at 2 months); however, in all coated samples the values decreased significantly, while in the control no. Furthermore, no significant differences were observed between samples, at 3 and 6 months of storage. The high values of moisture and water activity may be due to the samples having been kept refrigerated throughout storage. On the contrary, if the samples were stored at room temperature, probably the dehydration would occur rapidly (Bhisanbut et al., 2008).

\subsection{Reducing sugars}

At day 0 , reducing sugars in chestnuts were detected in low amounts $363 \mathrm{mg} / 100 \mathrm{~g} \mathrm{dw}$. These results are in conformity with previous studies in Portuguese cultivars, where sucrose were found in high amounts (3.71-24.17 g/100 g dw for "Aveleira" and "Boa Ventura" cultivars), while fructose $(0.57-5.32 \mathrm{~g} / 100 \mathrm{~g} \mathrm{dw}$ for "Judia" and "Boa ventura" cultivars) and glucose (0.96-6.79g/100 g dw for "Judia" and "Boa ventura" cultivars), both reducing sugars, were quantified in small quantities (Barreira et al., 2010). In fact the content of reducing sugars in chestnuts is low, but chestnuts are rich in starch, which can be hydrolyzed to glucose (reducing sugar), during storage. So, reducing sugars were determined along chestnuts storage in order to estimate the occurrence of this process. After one month of storage, a significant decrease was observed in all samples compared to the beginning. After this period, different behaviors were observed between the different treatments. At the end of storage (6 months) the coating samples did not show significant differences with the control, except the alginate coated ones, for which an increase was observed. This increase observed during the storage of alginate coated chestnuts, may be attributed to the increase of the activity of the enzymes responsible for the hydrolysis of starch and to the decrease of the rate of breaking of sugar by respiration (Bashir and Abu-Goukh, 2003). This increase in reducing sugar contents over the storage period was also observed by other authors, such as in ber (Mani et al., 2018) and guava (Wijewardana et al., 2014). So, in general terms edible coatings did not affect significantly the production and usage of reducing sugars throughout chestnuts storage, when compared to the uncoated. 


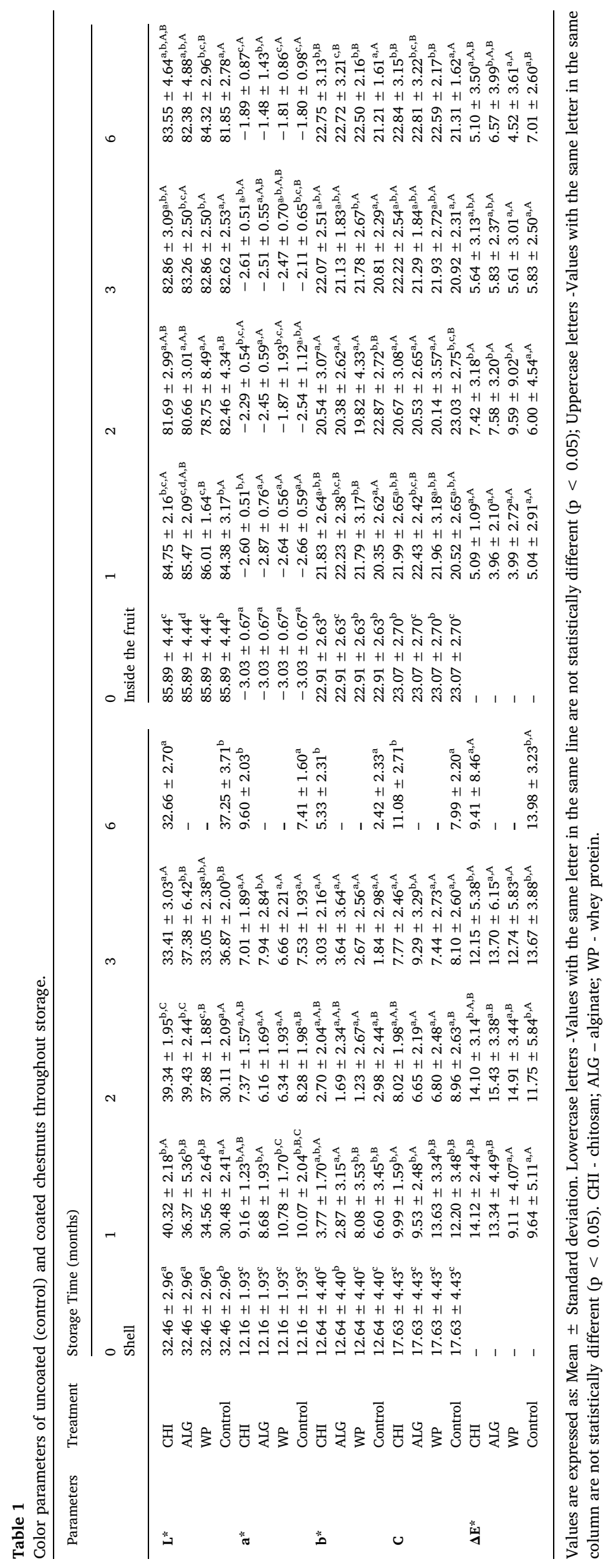


Table 2

Moisture content, $\mathrm{a}_{\mathrm{w}}$ and reducing sugars of uncoated (control) and coated chestnuts throughout storage.

\begin{tabular}{|c|c|c|c|c|c|c|}
\hline \multirow[t]{2}{*}{ Parameters } & \multirow[t]{2}{*}{ Treatment } & \multicolumn{5}{|c|}{ Storage Time (months) } \\
\hline & & 0 & 1 & 2 & 3 & 6 \\
\hline \multirow[t]{4}{*}{ Weight loss } & $\mathrm{CHI}$ & - & $0.93 \pm 0.15^{\mathrm{a}, \mathrm{A}}$ & $1.08 \pm 0.09^{\mathrm{a}, \mathrm{A}}$ & $2.63 \pm 0.58^{\mathrm{b}, \mathrm{A}}$ & * \\
\hline & ALG & & $1.41 \pm 0.16^{\mathrm{a}, \mathrm{A}, \mathrm{B}}$ & $1.87 \pm 1.08^{\mathrm{a}, \mathrm{A}}$ & $7.31 \pm 2.97^{\mathrm{b}, \mathrm{A}, \mathrm{B}}$ & \\
\hline & WP & & $1.63 \pm 0.25^{\mathrm{a}, \mathrm{B}}$ & $1.97 \pm 0.10^{\mathrm{a}, \mathrm{A}}$ & $14.60 \pm 2.13^{\mathrm{b}, \mathrm{B}}$ & \\
\hline & Control & & $1.29 \pm 0.23^{\mathrm{a}, \mathrm{A}, \mathrm{B}}$ & $2.01 \pm 0.11^{\mathrm{a}, \mathrm{A}}$ & $6.95 \pm 3.15^{\mathrm{b}, \mathrm{A}}$ & \\
\hline \multirow[t]{4}{*}{ Moisture (\%) } & $\mathrm{CHI}$ & $46.7 \pm 4.24^{\mathrm{a}}$ & $50.3 \pm 1.08^{\mathrm{a}, \mathrm{A}}$ & $50.4 \pm 3.44^{\mathrm{a}, \mathrm{A}}$ & $42.0 \pm 9.30^{\mathrm{a}, \mathrm{A}}$ & $44.4 \pm 5.07^{\mathrm{a}, \mathrm{A}}$ \\
\hline & ALG & $46.7 \pm 4.24^{\mathrm{a}}$ & $48.9 \pm 1.60^{\mathrm{a}, \mathrm{b}, \mathrm{A}}$ & $49.9 \pm 1.93^{\mathrm{a}, \mathrm{b}, \mathrm{A}}$ & $56.0 \pm 3.96^{\mathrm{b}, \mathrm{A}}$ & $46.3 \pm 3.43^{\mathrm{a}, \mathrm{A}}$ \\
\hline & WP & $46.7 \pm 4.24^{\mathrm{a}}$ & $53.4 \pm 1.07^{\mathrm{a}, \mathrm{b}, \mathrm{B}}$ & $55.5 \pm 3.37^{\mathrm{b}, \mathrm{A}}$ & $51.6 \pm 3.24^{\mathrm{a}, \mathrm{b}, \mathrm{A}}$ & $48.1 \pm 2.85^{\mathrm{a}, \mathrm{b}, \mathrm{A}}$ \\
\hline & Control & $46.7 \pm 4.24^{\mathrm{a}}$ & $52.2 \pm 0.97^{\mathrm{a}, \mathrm{B}}$ & $52.8 \pm 2.46^{\mathrm{a}, \mathrm{A}}$ & $50.7 \pm 2.32^{\mathrm{a}, \mathrm{A}}$ & $51.6 \pm 2.95^{\mathrm{a}, \mathrm{A}}$ \\
\hline \multirow[t]{4}{*}{$a_{w}$} & $\mathrm{CHI}$ & $0.972 \pm 0.01^{\mathrm{b}}$ & $0.970 \pm 0.01^{\mathrm{b}, \mathrm{A}}$ & $0.971 \pm 0.01^{\mathrm{b}, \mathrm{A}}$ & $0.969 \pm 0.01^{\mathrm{a}, \mathrm{b}, \mathrm{A}}$ & $0.954 \pm 0.01^{\mathrm{a}, \mathrm{A}}$ \\
\hline & ALG & $0.972 \pm 0.01^{\mathrm{b}}$ & $0.971 \pm 0.01^{\mathrm{b}, \mathrm{A}}$ & $0.972 \pm 0.01^{\mathrm{b}, \mathrm{A}}$ & $0.975 \pm 0.01^{\mathrm{b}, \mathrm{A}}$ & $0.959 \pm 0.01^{\mathrm{a}, \mathrm{A}}$ \\
\hline & WP & $0.972 \pm 0.01^{\mathrm{b}}$ & $0.976 \pm 0.01^{\mathrm{b}, \mathrm{A}}$ & $0.978 \pm 0.01^{\mathrm{b}, \mathrm{B}}$ & $0.972 \pm 0.01^{\mathrm{b}, \mathrm{A}}$ & $0.961 \pm 0.01^{\mathrm{a}, \mathrm{A}}$ \\
\hline & Control & $0.972 \pm 0.01^{\mathrm{a}, \mathrm{b}}$ & $0.977 \pm 0.01^{\mathrm{b}, \mathrm{A}}$ & $0.976 \pm 0.01^{\mathrm{b}, \mathrm{B}}$ & $0.972 \pm 0.01^{\mathrm{a}, \mathrm{b}, \mathrm{A}}$ & $0.969 \pm 0.01^{\mathrm{a}, \mathrm{A}}$ \\
\hline \multirow{4}{*}{$\begin{array}{l}\text { Reducing sugars } \\
\qquad(\mathrm{mg} \text { glucose } / 100 \mathrm{~g} \mathrm{dw})\end{array}$} & $\mathrm{CHI}$ & $363 \pm 49^{b}$ & $115 \pm 4^{\mathrm{a}, \mathrm{A}, \mathrm{B}}$ & $59 \pm 7^{\mathrm{a}, \mathrm{A}}$ & $61 \pm 20^{\mathrm{a}, \mathrm{A}, \mathrm{B}}$ & $301 \pm 31^{\mathrm{b}, \mathrm{A}, \mathrm{B}}$ \\
\hline & ALG & $363 \pm 49^{c}$ & $131 \pm 11^{\mathrm{b}, \mathrm{B}}$ & $51 \pm 8^{\mathrm{a}, \mathrm{A}}$ & $82 \pm 9^{\mathrm{b}, \mathrm{c}, \mathrm{B}, \mathrm{C}}$ & $360 \pm 22^{\mathrm{c}, \mathrm{B}}$ \\
\hline & WP & $363 \pm 49^{c}$ & $239 \pm 21^{\mathrm{b}, \mathrm{C}}$ & $101 \pm 12^{\mathrm{a}, \mathrm{B}}$ & $109 \pm 5^{\mathrm{a}, \mathrm{C}}$ & $288 \pm 11^{\mathrm{b}, \mathrm{A}, \mathrm{B}}$ \\
\hline & Control & $363 \pm 49^{c}$ & $88 \pm 2^{\mathrm{a}, \mathrm{A}}$ & $42 \pm 4^{\mathrm{a}, \mathrm{A}}$ & $49 \pm 5^{\mathrm{a}, \mathrm{A}}$ & $220 \pm 49^{\mathrm{b}, \mathrm{A}}$ \\
\hline
\end{tabular}

Values are expressed as: Mean \pm Standard deviation. Lowercase letters -Values with the same letter in the same line are not statistically different (p $<0.05$ ); Uppercase letters -Values with the same letter in the same column are not statistically different $(\mathrm{p}<0.05)$. CHI - chitosan; ALG - alginate; WP - whey protein. *After 6 months of storage it was not possible to determine the weight loss.

\subsection{Texture}

The texture parameters are described in Table 3. The skin of chestnuts functions mainly as a protection against external factors, as well as, it is involved in growth control. So, the skin strength is one of the factors of quality and safety of nut, as well as, it is important for consumer acceptance. In the present study, it was verified that at the end of storage, chestnuts coated with chitosan and whey protein, as well as, the control showed no significant differences compared to the beginning (day 0). On contrary, chestnuts coated with alginate presented a significant decrease in the maximum penetration force values, from $33 \mathrm{~N}$ (day 0) to $29 \mathrm{~N}$ ( 6 months). However, the differences among the edible coatings' samples and the control after 6 months of storage were not statistically significant. In general, some fluctuation in elasticity values was observed over the storage period for the different coatings applied. Regarding hardness, the alginate coated samples always remained with identical hardness, while in the other samples some variability was stated. Probably, this might be that during the alginate coating process, chestnuts were immersed in a calcium solution $\left(\mathrm{CaCl}_{2}\right)$, which is an effective firming agent due to the ability of calcium to bind cell wall polymers, to maintain its structure, and diminish the water solubility of pectic substances with the formation of calcium pectate (Howard and Buescher, 1990; Poovaiah, 1986). So, the addition of the crosslinking agent leads to fewer changes in the texture of the fruit.

Comparing the hardness values obtained after 6 months with those at beginning, no significant differences were observed in alginate and control, whereas in chitosan and whey protein a decrease in hardness was observed. Consequently, fruit softening may occur in these two types of coatings after 6 months of storage.

\subsection{Titratable acidity and total soluble solids}

The titratable acidity and soluble solids are the best maturity indicators for fruit ripeness and taste (Pesis et al., 2002). The TA and TSS contents of uncoated (control) and coated chestnuts are represented in Fig. 3. Regarding titratable acidity, as oxygen transfer rate can decrease when coatings are applied, anaerobic respiration may occur in chestnuts. When glucose is subjected to anaerobic fermentation, alcohol is produced, which decreases titratable acidity (Ball, 1997). Alcohol may cause off-flavor and rapid decay. So, we considered important to determine the titratable acidity. In the present work, a slight increase in total acidity up to 2 months of storage was observed in all samples. This result might be to the acidic properties that coatings have. The $\mathrm{pH}$ values of the solutions of chitosan, alginate, $\mathrm{CaCl}_{2}$ and whey protein were $4.73,6.72,5.55$ and 6.47 , respectively, showing their acid

Table 3

Texture parameters of uncoated (control) and coated chestnuts throughout storage.

\begin{tabular}{|c|c|c|c|c|c|c|}
\hline \multirow[t]{2}{*}{ Texture } & \multirow[t]{2}{*}{ Treatment } & \multicolumn{5}{|c|}{ Storage Time (months) } \\
\hline & & 0 & 1 & 2 & 3 & 6 \\
\hline \multirow[t]{4}{*}{ Maximum penetration force $(\mathrm{N})$} & $\mathrm{CHI}$ & $33 \pm 3^{\mathrm{a}, \mathrm{b}}$ & $32 \pm 4^{\mathrm{a}, \mathrm{b}, \mathrm{A}}$ & $34 \pm 4^{\mathrm{b}, \mathrm{A}}$ & $30 \pm 7^{\mathrm{a}, \mathrm{A}}$ & $31 \pm 5^{\mathrm{a}, \mathrm{A}}$ \\
\hline & ALG & $33 \pm 3^{b}$ & $33 \pm 2^{\mathrm{b}, \mathrm{A}, \mathrm{B}}$ & $33 \pm 4^{\mathrm{b}, \mathrm{A}}$ & $32 \pm 7^{\mathrm{a}, \mathrm{b}, \mathrm{A}}$ & $29 \pm 7^{\mathrm{a}, \mathrm{A}}$ \\
\hline & WP & $33 \pm 3^{\mathrm{a}, \mathrm{b}}$ & $34 \pm 4^{\mathrm{a}, \mathrm{b}, \mathrm{A}, \mathrm{B}}$ & $35 \pm 4^{\mathrm{b}, \mathrm{A}}$ & $33 \pm 7^{\mathrm{a}, \mathrm{b}, \mathrm{A}}$ & $31 \pm 5^{\mathrm{a}, \mathrm{A}}$ \\
\hline & Control & $33 \pm 3^{\mathrm{a}, \mathrm{b}}$ & $35 \pm 3^{\mathrm{b}, \mathrm{B}}$ & $34 \pm 5^{\mathrm{a}, \mathrm{b}, \mathrm{A}}$ & $32 \pm 4^{\mathrm{a}, \mathrm{b}, \mathrm{A}}$ & $32 \pm 4^{\mathrm{a}, \mathrm{A}}$ \\
\hline \multirow[t]{4}{*}{ Elasticity (mm) } & CHI & $2.63 \pm 1.26^{\mathrm{a}}$ & $2.51 \pm 0.98^{\mathrm{a}, \mathrm{A}}$ & $3.35 \pm 1.52^{\mathrm{a}, \mathrm{A}}$ & $3.11 \pm 1.36^{\mathrm{a}, \mathrm{A}}$ & $3.33 \pm 1.02^{\mathrm{a}, \mathrm{A}}$ \\
\hline & ALG & $2.63 \pm 1.26^{\mathrm{a}}$ & $4.22 \pm 1.56^{\mathrm{c}, \mathrm{B}}$ & $3.66 \pm 1.55^{\mathrm{b}, \mathrm{c}, \mathrm{A}}$ & $4.17 \pm 1.55^{\mathrm{c}, \mathrm{B}}$ & $3.07 \pm 0.65^{\mathrm{a}, \mathrm{b}, \mathrm{A}}$ \\
\hline & WP & $2.63 \pm 1.26^{\mathrm{a}}$ & $3.94 \pm 1.88^{\mathrm{b}, \mathrm{B}}$ & $4.01 \pm 1.75^{\mathrm{b}, \mathrm{A}}$ & $3.58 \pm 1.56^{\mathrm{a}, \mathrm{b}, \mathrm{A}, \mathrm{B}}$ & $3.19 \pm 0.95^{\mathrm{a}, \mathrm{b}, \mathrm{A}}$ \\
\hline & Control & $2.63 \pm 1.26^{\mathrm{a}}$ & $3.22 \pm 1.57^{\mathrm{a}, \mathrm{b}, \mathrm{A}, \mathrm{B}}$ & $3.74 \pm 1.80^{\mathrm{b}, \mathrm{A}}$ & $3.40 \pm 1.47^{\mathrm{a}, \mathrm{b}, \mathrm{A}, \mathrm{B}}$ & $3.23 \pm 1.38^{\mathrm{a}, \mathrm{b}, \mathrm{A}}$ \\
\hline \multirow[t]{4}{*}{ Hardness (N.s) } & $\mathrm{CHI}$ & $142 \pm 20^{\mathrm{b}}$ & $131 \pm 19^{\mathrm{b}, \mathrm{A}}$ & $146 \pm 24^{\mathrm{b}, \mathrm{A}}$ & $127 \pm 34^{\mathrm{b}, \mathrm{A}}$ & $107 \pm 16^{\mathrm{a}, \mathrm{A}}$ \\
\hline & ALG & $142 \pm 20^{\mathrm{a}}$ & $152 \pm 21^{\mathrm{a}, \mathrm{B}}$ & $155 \pm 20^{\mathrm{a}, \mathrm{A}, \mathrm{B}}$ & $143 \pm 30^{\mathrm{a}, \mathrm{B}}$ & $100 \pm 28^{\mathrm{a}, \mathrm{A}}$ \\
\hline & WP & $142 \pm 20^{\mathrm{b}}$ & $163 \pm 15^{\mathrm{c}, \mathrm{d}, \mathrm{B}, \mathrm{C}}$ & $168 \pm 20^{\mathrm{d}, \mathrm{B}}$ & $147 \pm 31^{\mathrm{b}, \mathrm{c}, \mathrm{B}}$ & $107 \pm 24^{\mathrm{a}, \mathrm{A}}$ \\
\hline & Control & $142 \pm 20^{\mathrm{a}}$ & $168 \pm 14^{\mathrm{c}, \mathrm{C}}$ & $159 \pm 19^{\mathrm{b}, \mathrm{c}, \mathrm{A}, \mathrm{B}}$ & $147 \pm 19^{\mathrm{a}, \mathrm{b}, \mathrm{B}}$ & $140 \pm 16^{\mathrm{a}, \mathrm{B}}$ \\
\hline
\end{tabular}

Values are expressed as: Mean \pm Standard deviation. Lowercase letters -Values with the same letter in the same line are not statistically different ( $\mathrm{p}<0.05$ ); Uppercase letters -Values with the same letter in the same column are not statistically different $(\mathrm{p}<0.05)$. CHI - chitosan; ALG - alginate; WP - whey protein. 

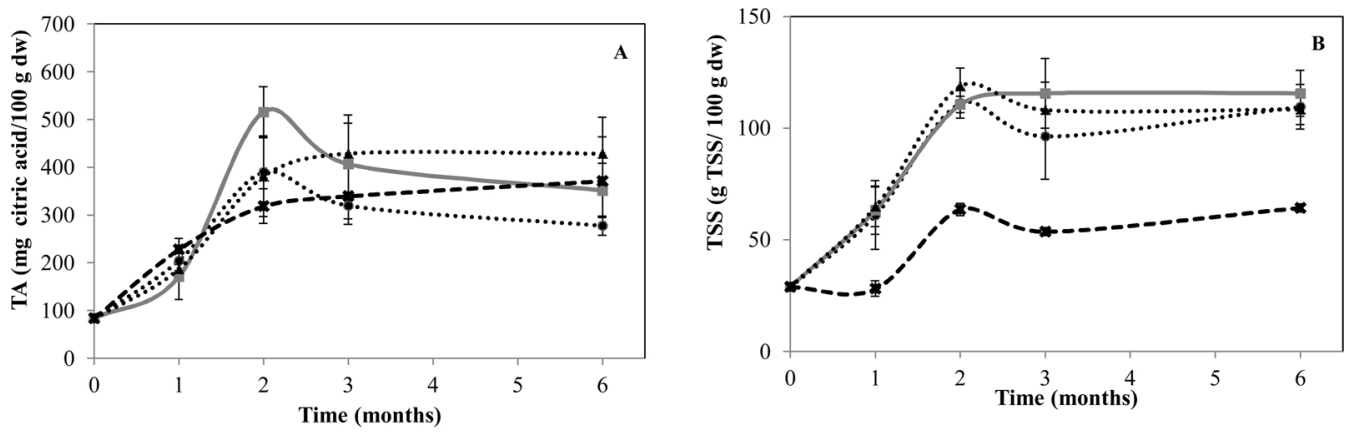

..•.. Chitosan $\rightarrow$-Alginate ….. Whey Protein -*-Control

Fig. 3. Titratable acidity (A) and total soluble solids (B) of uncoated (control) and coated chestnuts throughout storage.

character. Since coatings were placed outside chestnuts, by 2 months the TA may have increased due to the passage of possible coating compounds to the inside of the fruit. After this storage time, the passage of these compounds was no longer significant. Between 3 and 6 months the values of acidity remained almost constant and no significant differences were detected between samples ( $p>0.05$ ) (Fig. 3A). Comparing our data with others in coated fruits, the results were different. In most of the studies, the coated fruits showed a decrease in TA contents during storage (Taghinezhad and Ebadollahi, 2017; Chiabrando and Giacalone, 2016). However, most of the studies were performed during shorter storage periods (ex: 63 days for lemons (Taghinezhad and Ebadollahi, 2017) and 9 days for fresh-cut nectarines (Chiabrando and Giacalone, 2016)), due to these fruits being more perishable than chestnuts.

The TSS contents of coated and the control increased in the first two months, due to the hydrolysis of starch to simple sugars and to the conversion rate be higher than the utilization rate, remaining quite constant afterwards (Fig. 3B). However, the coated samples always showed higher values than control samples throughout storage, suggesting that chestnuts might have synthesized reducing sugars at a higher rate or have a lower utilization rate than the control. These results were different to those reported by Chiabrando and Giacalone (2016) for nectarines. Our TSS results were in agreement with the reducing sugars as the control sample always showed the lowest values throughout storage. Moreover, similar results to ours were reported by Wijewardana et al. (2014), who detected that in all coatings (cassava starch, rice bran, sun flower oil and bee wax) applied to guavas, the TSS values has increased with time.

\subsection{Microbial quality}

Fresh chestnuts contain large amounts of sugars and water which facilitates microbial growth, being this one of the main problem during storage (Bhisanbut et al., 2008). Significant differences ( $p<0.05$ ) between the counts of mesophilic, molds and yeast microorganisms in uncoated (control) and coated chestnuts are shown in Table 4. Chitosan coating applied on chestnuts had a marked effect in reducing mesophilic, molds and yeast counts as compared to the control, and to the alginate and whey protein coatings, after 6 months of storage. On the contrary, there were no significant differences between the control and the whey protein coating for aerobic mesophylls and between the control and the alginate coating for molds and yeasts. These results were expected because, at the end of 6 months of storage, the alginate and whey protein coated chestnuts, as well as the control, showed microbial growth visible to the human eye (Fig. 2). Until 3 months of storage, in what concerns aerobic mesophilic microorganisms, alginate coating showed no significant differences with the beginning (day 0), while in molds and yeasts a significant increase was observed. So, chitosan coating seemed to give some protection effect against aerobic mesophilic microorganisms, and yeasts and molds. On the contrary, whey protein coating did not protect chestnuts against microbial growth. Our results were in accordance with Chiabrando and Giacalone (2016), who also concluded that chitosan coating was the most effective in controlling microbial growth in nectarines, comparing with other coatings. Furthermore, some studies referred different mechanisms of chitosan against a wide range of microorganisms, namely: the ionic surface interaction resulting in wall cell leakage (Goy et al., 2016); the inhibition of the mRNA and protein synthesis via the penetration of chitosan into the nuclei of the microorganisms; and the formation of an external barrier, which can chelate metals and provoke the suppression of essential nutrients to microbial growth (Goy et al., 2009).

\section{Conclusion}

The different coatings studied showed distinctive effects on the physicochemical and microbial parameters of chestnuts throughout 6 months of storage. All coated samples, as well as the control, had similar behaviours for moisture, titratable acidity and $a_{w}$ contents throughout storage. On the contrary, TSS and reducing sugars increased in coated chestnuts compared to control. In color and texture parameters, little changes were observed during storage for coated samples. Chitosan coatings exhibited the lowest growth of microorganisms. In particularly, chitosan coating controlled the growth of microorganisms during 6 months of storage, appearing to be a promising preservation technique. However, more works should be done, in the future, on the effects of other edible coatings and chitosan coating on the sensory quality of chestnuts during storage, in order to select the best coating to be used by chestnuts producers and industrials.

\section{CRediT authorship contribution statement}

Luana Fernandes: Conceptualization, Methodology, Investigation, Data curation, Writing - original draft. Ermelinda L. Pereira: Conceptualization, Methodology, Data curation, Writing - review \& editing, Supervision, Project administration. Maria do Céu Fidalgo: Methodology, Investigation. Auryo Gomes: Methodology, Investigation. Elsa Ramalhosa: Conceptualization, Methodology, Data curation, Writing - review \& editing, Supervision, Project administration.

\section{Declaration of Competing Interest}

The authors declare that they have no known competing financial interests or personal relationships that could have appeared to 
Table 4

Mean counts ( $\log \mathrm{cfu} / \mathrm{g} \pm$ standard deviation) of aerobic mesophilic microorganisms, yeasts and molds analyzed in uncoated (control) and coated chestnuts throughout storage.

\begin{tabular}{|c|c|c|c|c|c|c|}
\hline \multirow[t]{2}{*}{ Microbial groups } & \multirow[t]{2}{*}{ Treatment } & \multicolumn{5}{|c|}{ Storage Time (months) } \\
\hline & & 0 & 1 & 2 & 3 & 6 \\
\hline \multirow[t]{4}{*}{ Aerobic mesophilic } & $\mathrm{CHI}$ & $4.45 \pm 0.39^{b}$ & $2.45 \pm 1.30^{\mathrm{a}, \mathrm{A}}$ & $2.84 \pm 0.73^{\mathrm{a}, \mathrm{b}, \mathrm{A}}$ & $3.68 \pm 0.20^{\mathrm{a}, \mathrm{b}, \mathrm{A}}$ & $4.30 \pm 0.26^{\mathrm{a}, \mathrm{b}, \mathrm{A}}$ \\
\hline & ALG & $4.45 \pm 0.39^{\mathrm{a}}$ & $4.56 \pm 0.27^{\mathrm{a}, \mathrm{A}, \mathrm{B}}$ & $4.70 \pm 0.19^{\mathrm{a} . \mathrm{B} . \mathrm{C}}$ & $5.07 \pm 0.55^{\mathrm{a}, \mathrm{b}, \mathrm{B}}$ & $6.17 \pm 0.58^{\mathrm{b}, \mathrm{B}}$ \\
\hline & $\mathrm{WP}$ & $4.45 \pm 0.39^{\mathrm{a}}$ & $6.58 \pm 0.82^{\mathrm{b}, \mathrm{B}}$ & $6.29 \pm 0.81^{\mathrm{b}, \mathrm{C}}$ & $6.81 \pm 0.77^{\mathrm{b}, \mathrm{C}}$ & $7.52 \pm 0.36^{\mathrm{b}, \mathrm{C}}$ \\
\hline & Control & $4.45 \pm 0.39^{\mathrm{a}}$ & $5.01 \pm 0.41^{\mathrm{a}, \mathrm{B}}$ & $4.63 \pm 0.59^{\mathrm{a}, \mathrm{B}}$ & $5.10 \pm 0.11^{\mathrm{a}, \mathrm{B}}$ & $6.71 \pm 0.47^{\mathrm{b}, \mathrm{B}, \mathrm{C}}$ \\
\hline \multirow[t]{4}{*}{ Molds and yeasts } & $\mathrm{CHI}$ & $3.74 \pm 0.12^{\mathrm{a}, \mathrm{b}}$ & $2.65 \pm 1.65^{\mathrm{a}, \mathrm{A}}$ & $4.24 \pm 0.52^{\mathrm{a}, \mathrm{b}, \mathrm{A}}$ & $4.59 \pm 0.02^{\mathrm{a}, \mathrm{b}, \mathrm{A}}$ & $5.24 \pm 0.11^{\mathrm{b}, \mathrm{A}}$ \\
\hline & ALG & $3.74 \pm 0.12^{\mathrm{a}}$ & $4.81 \pm 0.11^{\mathrm{b}, \mathrm{A}, \mathrm{B}}$ & $4.98 \pm 0.33^{\mathrm{b}, \mathrm{A}}$ & $5.56 \pm 0.24^{\mathrm{c}, \mathrm{B}}$ & $6.03 \pm 0.15^{\mathrm{c}, \mathrm{B}}$ \\
\hline & WP & $3.74 \pm 0.12^{\mathrm{a}}$ & $5.72 \pm 0.45^{\mathrm{b}, \mathrm{B}}$ & $6.27 \pm 0.13^{\mathrm{b}, \mathrm{c}, \mathrm{B}}$ & $6.42 \pm 0.24^{\mathrm{c}, \mathrm{C}}$ & $6.51 \pm 0.03^{\mathrm{c}, \mathrm{C}}$ \\
\hline & Control & $3.74 \pm 0.12^{\mathrm{a}}$ & $4.81 \pm 0.74^{\mathrm{b}, \mathrm{A}, \mathrm{B}}$ & $4.72 \pm 0.10^{\mathrm{b}, \mathrm{A}}$ & $5.21 \pm 0.24^{\mathrm{b}, \mathrm{B}}$ & $6.24 \pm 0.06^{\mathrm{c}, \mathrm{B}}$ \\
\hline
\end{tabular}

Values are expressed as: Mean \pm Standard deviation. Lowercase letters -Values with the same letter in the same line are not statistically different (p $<0.05$ ); Uppercase letters -Values with the same letter in the same column are not statistically different $(\mathrm{p}<0.05)$. CHI - chitosan; ALG - alginate; WP - whey protein.

influence the work reported in this paper.

\section{Acknowledgements}

The authors acknowledge the financial support provided to ValorCast Project (PDR2020-101-032034), as part of a community initiative promoted by PDR2020 and co-financed by FEADER, within the Portugal 2020, and to the Tranfer + Castanha Project (NORTE-010246-FEDER-000026), financed by the Program NORTE 2020 - SIAC. The authors are also grateful to FCT (Portugal) and FEDER under Program PT2020 for financial support to CIMO (UID/AGR/00690/ 2019).

\section{References}

Alleoni, A.C.C., Jacomino, A.P., Rosa, A.S., 2006. 'Pêra' orange coating with whey protein concentrate film associated to plasticizers. Pesquisa Agropecuária Brasileira 41, 1221-1226.

Amanatidou, A., Slump, R.A., Gorris, L.G.M., Smid, E.J., 2000. High oxygen and high carbon dioxide modified atmospheres for shelf life extension of minimally processed carrots. J. Food Sci. 65, 61-66.

Ball, J.A., 1997. Evaluation of Two Lipid-based Edible Coatings for Their Ability to Preserve Post Harvest Quality of Green Bell Peppers. Master Thesis. Faculty of the Virginia Polytechnic Institute and State University, Blacksburg, Virginia, USA.

Barreira, J.C.M., Casal, S., Ferreira, I.C.F.R., Peres, A.M., Pereira, J.A., Oliveira, M.B.P.P., 2012. Chemical characterization of chestnut cultivars from three consecutive years: chemometrics and contribution for authentication. Food Chem. Toxicol. 50, 2311-2317.

Barreira, J.C.M., Pereira, J.A., Oliveira, M.B., Ferreira, I.C.F.R., 2010. Sugars profiles of different chestnut (Castanea sativa Mill.) and almond (Prunus dulcis) cultivars by HPLC-RI. Plant Foods Hum. Nutr. 65, 38-43.

Bashir, H.A., Abu-Goukh, A.B.A., 2003. Compositional changes during guava fruit ripening. Food Chem. 80, 557-563.

Bhisanbut, A., Shin, J., Harte, J., Fulbright, D., Dolan, K., Harte, B., 2008. The extension of chestnut product quality using modified atmosphere packaging and vacuum skin packaging. In: $16^{\text {th }}$ IAPRI World Conference on Packaging. $8^{\text {th }}$ to $12^{\text {th }}$ June, Bangkok, Thailand.

Blomhoff, R., Carlsen, M.H., Andersen, L.F., Jacobs, Jr D.R., 2006. Health benefits of nuts: potential role of antioxidants. Br. J. Nutr. 96, S52-S60.

Campos, C.A., Gerschenson, L.N., Flores, S.K., 2011. Development of edible films and coatings with antimicrobial activity. Food Bioproc. Tech. 4, 849-875.

Chiabrando, V., Giacalone, G., 2016. Effect of chitosan and sodium alginate edible coatings on the postharvest quality of fresh-cut nectarines during storage. Fruits 71 , 79-85.

Chien, P.-J., Sheu, F., Yang, F.-H., 2007. Effects of edible chitosan coating on quality and shelf life of sliced mango fruit. J. Food Eng. 78, 225-229.

Cisneros-Zevallos, L., Krochta, J.M., 2003. Whey protein coatings for fresh fruits and relative humidity effects. J. Food Sci. 68, 176-181.

Conca, K.R., Yang, T.C.S., 1993. Edible food barrier coatings. In: Ching, C., Kplan, D.,
Thomas, E. (Eds.), Biodegradable Polymers and Packaging. Techonomic Publishing Co., Inc., Lancaster, Pennsylvania, pp. 357-369.

DAGV, 2018. Procedure Manual - Export of Fresh Chestnuts Subjected to Treatment With Hot Water in Continuous System. Procedure to Be Adopted at the Storage and Packing Centrals of Chestnuts (version 01).

Goy, R.C., Morais, S.T.B., Assis, O.B.G., 2016. Evaluation of the antimicrobial activity of chitosan and its quaternized derivative on E. coli and S. aureus growth. Rev. Bras. Farmacogn. 26, 122-127.

Goy, R.C., Britto, D.A., Odilio, B.G., 2009. A review of the antimicrobial activity of chitosan. Polmeros 19 (3), 241-247.

Gounga, M.E., Omar, K.A., Amadou, I., Xu, S.-Y., 2017. Chocolate coating effect on whey protein isolate-pullulan-coated freeze-dried chestnut. Am. J. Food Sci. Technol. 5, 70-77.

Gounga, M.E., Xu, S.-Y., Wang, Z., 2007. Sensory attributes of freshly roasted and roasted freeze dried Chinese chestnut (Castanea mollissima) coated with whey protein isolatepullulan edible coating. Int. J. Agric. Res. 2, 959-964.

Howard, L.R., Buescher, R.W., 1990. Cell wall characteristics and firmness of fresh pack cucumber pickles affected by pasteurization and calcium chloride. J. Food Biochem. $14,31-43$.

INE (Instituto Nacional de Estatística), 2017. Estatísticas Agrícolas. ISBN 978-989-250445-2. .

Lin, D., Zhao, Y., 2007. Innovations in the development and application of edible coatings for fresh and minimally processed fruits and vegetables. Compr. Rev. Food Sci. Food Saf. 6, 61-75.

Mani, A., Prasanna, V.S.S.V., Halder, S., Praveena, J., 2018. Efficacy of edible coatings blended with aloe vera in retaining post-harvest quality and improving storage attributes in Ber (Ziziphus mauritiana Lamk.). Int. J. Chem. Stud. 6, 1727-1733.

Nair, M.S., Saxena, A., Kaur, C., 2018. Effect of chitosan and alginate based coatings enriched with pomegranate peel extract to extend the postharvest quality of guava (Psidium guajava L.). Food Chem. 240, 245-252.

NP-1421, 1977. Foodstuffs derived from fruit and vegetables. Determination of acidity. In: Direcção-Geral da Qualidade (Ed.), Portuguese Standard, $1^{\text {st }}$ ed. Portuguese Institute of Quality, Lisbon, Portugal, pp. 3.

Pesis, E., Dvir, O., Feygenberg, O., Arie, R.B., Ackerman, M., Lichter, A., 2002. Production of acetaldehyde and ethanol during maturation and modified atmosphere storage of litchi fruit. Postharvest Biol. Technol. 26, 157-165.

Poovaiah, B., 1986. Role of calcium in prolonging storage life of fruits and vegetables. Food Technol. 40, 86-89.

Regalado, C., Pérez-Pérez, C., Lara-Cortés, E., García-Almendarez, B., 2006. Whey protein based edible food packaging films and coatings. In: Guevara-González, Ramón Gerardo, Torres-Pacheco, Irineo (Eds.), Advances in Agricultural and Food Biotechnology, pp. 237-261 Chapter 11, ISBN: 81-7736-269-0.

Taghinezhad, E., Ebadollahi, A., 2017. Potential application of chitosan-clay coating on some quality properties of lemon during storage. AgricEngInt: CIGR J. 19, 189-194.

Varasteh, F., Arzani, K., Barzegar, M., Zamani, Z., 2017. Pomegranate (Punica granatum L.) fruit storability improvement using pre-storage chitosan coating technique. J. Agric. Sci. Technol. 19, 389-400.

Wijewardana, R.M.N.A., Karunathilake, K.N., Jayawardana, N.W.I.A., 2014. Development of edible coating for shelf life extension of guava. Focus. Mod. Food Ind. 3, 29-34.

Yaman, O., Bayoindirli, L., 2002. Effects of an edible coating and cold storage on shelf-life and quality of cherries. Lebensm. Wiss. Technol. 35, 146-150.

Zhang, D., Quantick, P.C., 1998. Antifungal effects of chitosan coating on fresh strawberries and raspberries during storage. J. Hortic. Sci. Biotechnol. 73 (6), 763-767. 